\title{
The presence of Rhizoctonia solani on potato tubers of ware potatoes depending on the method of application of the soil fertilizer UGmax
}

\author{
Występowanie Rhizoctonia solani na bulwach ziemniaka jadalnego \\ w zależności od sposobów stosowania Użyźniacza Glebowego UGmax
}

\author{
Alicja Baranowska ${ }^{1 *}$, Krystyna Zarzecka $^{2}$, Iwona Mystkowska ${ }^{1}$, Marek Gugała ${ }^{2}$
}

\section{Summary}

The aim of the study was to determine the occurrence of Rhizoctonia solani on tubers of ware potatoes depending on the method of application of the soil fertilizer UGmax. The studies were conducted at the Agricultural Experimental Farm of the University of Natural Sciences and Humanities in Siedlce on the IVa soil valuation class. The examined factors included variety and method of the soil fertilizer UGmax application. Two medium-early varieties of ware potato (Satina and Tajfun) and five ways of using the soil fertilizer UGmax, at different doses and terms were used. The studies showed that the methods of application of the soil fertilizer UGmax significantly reduced the occurrence of black scurf on tubers, the average degree of tuber infestation and the average degree of infestation on infested tubers.

Key words: Rhizoctonia solani; black scurf; soil fertilizer UGmax; potato

\section{Streszczenie}

Celem badań było określenie występowania Rhizoctonia solani na bulwach ziemniaka jadalnego w zależności od sposobów stosowania Użyźniacza Glebowego UGmax. Badania przeprowadzono w Rolniczej Stacji Doświadczalnej Uniwersytetu Przyrodniczo-Humanistycznego w Siedlcach. Eksperyment założono na glebie klasy bonitacyjnej IVa, metodą losowanych podbloków w trzech powtórzeniach. Badanymi czynnikami były: I - dwie średnio wczesne odmiany ziemniaka jadalnego - Satina i Tajfun, II - pięć sposobów stosowania Użyźniacza Glebowego UGmax w różnych dawkach i terminach. W wyniku przeprowadzonych badań wykazano, że Użyźniacz Glebowy UGmax istotnie wpływał na ograniczenie występowania rizoktoniozy na bulwach, na średni stopień porażenia próby i średni stopień porażenia bulw porażonych.

Słowa kluczowe: Rhizoctonia solani; rizoktonioza; Użyźniacz Glebowy UGmax; ziemniak

\footnotetext{
${ }^{1}$ Państwowa Szkoła Wyższa im. Papieża Jana Pawła II w Białej Podlaskiej Zakład Rolnictwa

Sidorska 95/97, 21-500 Biała Podlaska

${ }^{2}$ Uniwersytet Przyrodniczo-Humanistyczny w Siedlcach

Katedra Agrotechnologii

Prusa 14, 08-110 Siedlce

*corresponding author: alabar@tlen.pl
} 


\section{Wstęp / Introduction}

Ziemniak jest rośliną trudną w uprawie. Wegetatywny sposób rozmnażania powoduje, że uprawy ziemniaka narażone są na występowanie wielu groźnych chorób i szkodników. Patogeny często przenoszone są wraz z sadzeniakami, stanowiąc źródło zakażenia nowej plantacji. Jedną z najgroźniejszych chorób, obok chorób wirusowych i zarazy, występujących na plantacjach ziemniaka jest rizoktonioza ziemniaka (Rhizoctonia solani) (Zimny i wsp. 2006; Atkinson i wsp. 2010). Chorobę tę wywołuje grzyb z gatunku Rhizoctonia solani Kühn (stadium doskonałe Thanathephorus cucumeris). Patogen ten zimuje $\mathrm{W}$ postaci sklerocji będących formami przetrwalnikowymi na bulwach, w glebie lub w postaci grzybni na resztkach roślinnych. Wiosną w sprzyjających warunkach sklerocja kiełkują uszkadzając rozwijające się kiełki ziemniaka - jest to najgroźniejsza forma choroby. Następnie powodują próchnienie podstawy łodyg, a pod koniec okresu wegetacji na bulwach tworzą się czarne, przyklejone do skórki sklerocja, wielkości od kilku do kilkunastu milimetrów (tzw. ospowatość bulw), które po zbiorze pozostają na perydermie bulw przez cały okres ich przechowywania. Sklerocja, stanowiące formę przetrwalnikową grzyba, są źródłem zakażenia w następnym sezonie wegetacyjnym, powodując gnicie kiełków i infekcję roślin potomnych (Bernat i Osowski 2006; Lehtonen i wsp. 2008a, b; Wales i wsp. 2008).

W ostatnich latach obserwuje się coraz większe zainteresowanie praktyki rolniczej różnego rodzaju preparatami i użyźniaczami glebowymi, które przyspieszają proces przywracania równowagi biologicznej i dobrostanu gleby oraz poprawiają zdrowotność i odporność roślin na czynniki chorobotwórcze (Zarzecka i wsp. 2011).

Celem badań było określenie wpływu Użyźniacza Glebowego UGmax na występowanie Rhizoctonia solani na bulwach ziemniaka jadalnego.

\section{Materiały i metody / Materials and methods}

Doświadczenie polowe z zastosowaniem Użyźniacza Glebowego UGmax przeprowadzono w latach 2008-2010 w Rolniczej Stacji Doświadczalnej należącej do Uniwersytetu Przyrodniczo-Humanistycznego w Siedlcach. Badania polowe prowadzono na glebie zaliczanej do kompleksu żytniego bardzo dobrego, klasy bonitacyjnej IVa, o odczynie lekko kwaśnym i kwaśnym ( $\mathrm{pH}_{\mathrm{KCl}}$ 4,81-5,91). Doświadczenie założono metodą losowanych podbloków, w trzech powtórzeniach. Badanymi czynnikami były: odmiana oraz sposób aplikacji Użyźniacza Glebowego UGmax. Ocenie poddano dwie średnio wczesne odmiany ziemniaka jadalnego - Satina i Tajfun oraz pięć sposobów stosowania preparatu UGmax w różnych dawkach i terminach: 1 - obiekt kontrolny bez UGmax, 2 - UGmax doglebowo przed sadzeniem w dawce $1,0 \mathrm{dm}^{3} / \mathrm{ha}$, 3 - UGmax doglebowo przed sadzeniem w dawce $0,5 \mathrm{dm}^{3} / \mathrm{ha}$, przy wysokości roślin $10-15 \mathrm{~cm} \mathrm{i} \mathrm{w} \mathrm{fazie}$ pąków kwiatowych po $0,25 \mathrm{dm}^{3} / \mathrm{ha}, 4$ - UGmax przed sadzeniem $\mathrm{w}$ dawce $1,0 \mathrm{dm}^{3} /$ ha i przy wysokości roślin
10-15 cm i w fazie pąków kwiatowych po $0,5 \mathrm{dm}^{3} / \mathrm{ha}$, 5 - UGmax dolistnie przy wysokości roślin 10-15 cm i w fazie pąków kwiatowych po $0,5 \mathrm{dm}^{3} /$ ha. Użyźniacz Glebowy UGmax jest ekstraktem z kompostu zawierającym szczepionkę mikroorganizmów glebowych. W jego skład wchodzą: drożdże, bakterie kwasu mlekowego, bakterie Pseudomonas, Azotobacter i promieniowce oraz makro- i mikroelementy: potas (3500 mg/l), azot (1200 mg/l), siarka (1000 mg/l), fosfor $(500 \mathrm{mg} / \mathrm{l})$, sód (200 mg/l), magnez (100 mg/l), cynk (20 mg/l), mangan (0,3 mg/l) (Trawczyński 2007). Użyźniacz rozpuszczano w $300 \mathrm{dm}^{3}$ wody w przeliczeniu na 1 ha. Jesienią, przed założeniem doświadczenia stosowano obornik w dawce $25 \mathrm{t} / \mathrm{ha}$ oraz nawożenie fosforowe $\mathrm{P}-44,0 \mathrm{~kg} / \mathrm{ha}$ (superfosfat potrójny 46\%) i potasowe $\mathrm{K}-124,5 \mathrm{~kg} / \mathrm{ha}$ (sól potasowa 60\%), a wiosną nawożenie azotowe (saletra amonowa 34\%) w dawce $100 \mathrm{~kg} \mathrm{~N} / \mathrm{ha}$. Bulwy ziemniaka sadzono w rozstawie rzędów 67,5 cm, co 37 cm w rzędzie, w drugiej dekadzie kwietnia. Przeciwko chwastom, około 7 dni przed wschodami roślin ziemniaka zastosowano mieszaninę herbicydów Command 480 SC $\left(0,2 \mathrm{dm}^{3} / \mathrm{ha}\right)$ i Afalon Dyspersyjny 450 SC $\left(1,0 \mathrm{dm}^{3} / \mathrm{ha}\right)$. W okresie wegetacji plantację chroniono insektycydami: Apacz 50 WG (40,0 g/ha) i Actara 25 WG (80,0 g/ha) oraz preparatami: Ridomil Gold MZ 68 WG (2,0 kg/ha) i Dithane 455 SC (2,0 kg/ha). Zbioru dokonywano w okresie dojrzałości technologicznej bulw, w pierwszej dekadzie września.

W każdym roku prowadzenia badań oceniano porażenie bulw ziemniaka przez $R$. solani. Losowo z każdego obiektu doświadczenia pobierano 100 bulw i określano procentowy udział bulw porażonych, średni stopień porażenia bulw (wszystkich poddanych ocenie) i stopień porażenia bulw z objawami ospowatości. Nasilenie objawów ospowatości bulw oceniano posługując się 9-stopniową skalą, w której $1^{\circ}$ - oznacza ponad $25 \%$ pokrycia powierzchni bulwy sklerocjami, $9^{\circ}$ - brak objawów (bulwy zdrowe) (Roztropowicz 1999).

Wyniki badań opracowano statystycznie za pomocą analizy wariancji, a istotność różnic testowano testem Tukeya przy poziomie istotności p $=0,05$.

Podczas prowadzenia badań panowały zróżnicowane warunki pogodowe. W roku 2008 temperatura powietrza była zbliżona do temperatury panującej $\mathrm{w}$ okresie wieloletnim i wynosiła średnio $14,7^{\circ} \mathrm{C}$. Natomiast opady były większe, niż w okresie wieloletnim o $96,2 \mathrm{~mm}$, ale były równomiernie rozłożone $\mathrm{w}$ poszczególnych miesiącach wegetacji. Był to sezon sprzyjający wzrostowi i rozwojowi roślin ziemniaka oraz jego plonowaniu. W 2009 roku opady były rozłożone nierównomiernie, a miesiąc czerwiec był bardzo wilgotny - suma opadów w tym miesiącu wynosiła 145,2 mm. Również temperatura powietrza w miesiącu czerwcu była najniższa w stosunku do pozostałych lat badań i wynosiła średnio $15,7^{\circ} \mathrm{C}$. Rok 2010 był cieplejszy niż poprzednie sezony, a opady były nierównomiernie rozłożone $\mathrm{w}$ poszczególnych miesiącach wegetacji. Przekraczały one średnią sumę z okresu wieloletniego o $184,5 \mathrm{~mm}$, był to sezon najbardziej wilgotny (tab. 1). 
Tabela 1. Opady i temperatury powietrza w sezonach wegetacyjnych 2008-2010 według Stacji Meteorologicznej w Zawadach Table 1. Rainfalls and air temperatures in 2008-2010 vegetation seasons at the Zawady Meteorological Station

\begin{tabular}{|c|c|c|c|c|c|c|c|}
\hline \multirow{2}{*}{ Lata - Years } & \multicolumn{6}{|c|}{ Miesiące - Months } & \multirow{2}{*}{$\begin{array}{c}\text { Suma/Średnio } \\
\text { Mean/Sum } \\
\text { IV-IX }\end{array}$} \\
\hline & IV & $\mathrm{V}$ & VI & VII & VIII & IX & \\
\hline \multicolumn{8}{|c|}{ Opady - Rainfalls [mm] } \\
\hline 2008 & 28,2 & 85,6 & 49,0 & 69,8 & 75,4 & 63,4 & 371,4 \\
\hline 2009 & 8,1 & 68,9 & 145,2 & 26,4 & 80,9 & 24,9 & 354,4 \\
\hline 2010 & 10,7 & 93,2 & 62,6 & 77,0 & 106,3 & 109,9 & 459,7 \\
\hline $\begin{array}{l}\text { Średnia } z \text { lat } \\
1987-2000 \\
\text { The average over } \\
\text { the years } 1987-2000\end{array}$ & 38,6 & 44,1 & 52,4 & 49,8 & 43,0 & 47,3 & 275,2 \\
\hline \multicolumn{8}{|c|}{ Temperatura - Temperature $\left[{ }^{\circ} \mathrm{C}\right]$} \\
\hline 2008 & 9,1 & 12,7 & 17,4 & 18,4 & 18,5 & 12,2 & 14,7 \\
\hline 2009 & 10,3 & 12,9 & 15,7 & 19,4 & 17,7 & 14,6 & 15,1 \\
\hline 2010 & 8,9 & 14,0 & 17,4 & 21,6 & 19,8 & 11,8 & 15,6 \\
\hline $\begin{array}{l}\text { Średnia } \mathrm{z} \text { lat } \\
1987-2000 \\
\text { The average over } \\
\text { the years 1987-2000 }\end{array}$ & 7,8 & 12,5 & 17,2 & 19,2 & 18,5 & 13,1 & 14,7 \\
\hline \multicolumn{8}{|c|}{ Współczynnik hydrotermiczny Sielianinowa - Sielianinow’s hydrothermic coefficients* } \\
\hline 2008 & 1,04 & 2,18 & 0,94 & 1,25 & 1,36 & 1,73 & 1,39 \\
\hline 2009 & 0,26 & 1,72 & 3,08 & 0,44 & 1,48 & 0,57 & 1,28 \\
\hline 2010 & 0,40 & 2,14 & 1,20 & 1,15 & 1,74 & 3,10 & 1,61 \\
\hline
\end{tabular}

*wartość współczynnika (Bac i wsp. 1998) - coefficient value (Bac at al. 1998)

$<0,5$ - silna posucha - severe drought

0,51-0,69 - posucha - semi drought

0,70-0,99 - słaba posucha - poor drough

$\geq 1$ - brak posuchy - lack of drought

\section{Wyniki i dyskusja / Results and discussion}

Jedną z powszechnie występujących chorób na plantacjach ziemniaka jest rizoktonioza, która występuje w trzech formach, jako: zgnilizna kiełków, próchnienie podstawy łodyg i ospowatość bulw (Sadowski 2006). Obecnie wielu autorów zwraca uwagę na zastosowanie w produkcji roślinnej, w tym również ziemniaka różnego rodzaju preparatów mikrobiologicznych, efektywnych mikroorganizmów i użyźniaczy glebowych, poprawiających zdrowotność roślin i przyczyniających się do wzbudzenia naturalnych sił obronnych roślin (Walters i wsp. 2011). Jednak możliwość wykorzystania preparatów mikrobiologicznych w praktyce rolniczej nie jest jeszcze w pełni poznana. Wynika ona z krótkiego okresu badań oraz ich lokalnego zasięgu (Boligłowa i Gleń 2008).

W badaniach własnych Użyźniacz Glebowy UGmax istotnie zmniejszał występowanie ospowatości na bulwach uprawianych odmian ziemniaka w porównaniu do obiektu kontrolnego, na którym nie stosowano preparatu UGmax (tab. 2, 3, 4). W wyniku przeprowadzonych badań stwierdzono, że procentowy udział bulw $\mathrm{z}$ objawami rizoktoniozy wynosił przeciętnie $7,7 \%$, średni stopień porażenia próby 8,73 , a stopień porażenia bulw 6,48 w 9-stopniowej skali (tab. 2, 3, 4). Udział bulw z objawami rizoktoniozy zależał od sposobu stosowania Użyźniacza Glebowego UGmax i odmiany. Mniejszy udział bulw z objawami rizoktoniozy odnotowano na obiektach 3. i 4. (średnio 5,7\% i 5,0\%), na których preparat UGmax stosowano trzykrotnie (doglebowo przed sadzeniem bulw, następnie przy wysokości roślin 10-15 cm i w fazie pąków kwiatowych) (tab. 2). Podobne wyniki badań uzyskał Bernat (2007) oraz Zarzecka i wsp. (2011), którzy odnotowali mniejszy udział bulw porażonych patogenem na obiektach, na których stosowano preparat UGmax. Natomiast Jeske i wsp. (2015) w swoich badaniach nie wykazali wpływu Użyźniacza Glebowego UGmax na zdrowotność bulw ziemniaka.

Mniejszy udział bulw z objawami rizoktoniozy wystąpił u odmiany Satina - średnio 6,8\% niż u odmiany Tajfun - średnio 8,6\% (tab. 2). Odmiana Satina charakteryzowała się również mniejszym stopniem porażenia bulw niż odmiana Tajfun. Wartość ta w skali 1-9 wynosiła odpowiednio dla odmiany Satina - 6,13 i Tajfun - 6,82. Zróżnicowaną reakcję odmian ziemniaka na porażenie patogenem wykazali również Wróbel (2006), Zarzecka i wsp. (2011) oraz Cwalina-Ambroziak i Wróbel (2005).

W badaniach własnych wykazano, że warunki pogodowe panujące $\mathrm{w}$ latach prowadzenia badań miały istotny wpływ na procentowy udział bulw porażonych patogenem, średni stopień porażenia próby i stopień porażenia bulw (tab. 5). Najmniejszy procent bulw porażonych patogenem odnotowano w 2010 roku (tab. 5), w którym średnia temperatura powietrza była najwyższa $\mathrm{w}$ stosunku do 
Tabela 2. Udział bulw z objawami rizoktoniozy w zależności od odmiany i sposobów stosowania UGmax w \%

Table 2. Share of tubers with black scurf symptoms depending on the cultivars and methods of use UGmax in \%

\begin{tabular}{|c|c|c|c|}
\hline \multirow{3}{*}{$\begin{array}{l}\text { Sposoby stosowania UGmax } \\
\text { Methods of use UGmax }\end{array}$} & \multirow{2}{*}{\multicolumn{2}{|c|}{$\begin{array}{c}\text { Udział bulw porażonych } \\
\text { Share of infected tubers } \\
\text { odmiany ziemniaka } \\
\text { potato cultivars }\end{array}$}} & \multirow{3}{*}{$\begin{array}{l}\text { Średnio } \\
\text { Mean }\end{array}$} \\
\hline & & & \\
\hline & Satina & Tajfun & \\
\hline $\begin{array}{l}\text { Obiekt kontrolny - pielęgnacja mechaniczna } \\
\text { Control object - mechanical weeding }\end{array}$ & 12,2 & 12,8 & 12,5 \\
\hline UGmax $1,0+0 \mathrm{dm}^{3} / \mathrm{ha}$ & 5,8 & 8,5 & 7,1 \\
\hline UGmax $0,5+0,25+0,25 \mathrm{dm}^{3} / \mathrm{ha}$ & 5,1 & 6,1 & 5,7 \\
\hline UGmax $1,0+0,25+0,25 \mathrm{dm}^{3} / \mathrm{ha}$ & 4,7 & 5,2 & 5,0 \\
\hline UGmax $0+0,5+0,5 \mathrm{dm}^{3} / \mathrm{ha}$ & 6,1 & 10,6 & 8,4 \\
\hline Średnio - Mean & 6,8 & 8,6 & 7,7 \\
\hline $\begin{array}{l}\text { NIR }(0,05) \text { - LSD }(0.05) \text { dla - for: } \\
\text { Odmiany - Cultivars } \\
\text { Sposoby stosowania UGmax - Methods of use } \\
\text { Odmiany } \times \text { sposoby stosowania UGmax - Cul }\end{array}$ & JGmax & & $\begin{array}{l}1,5 \\
4,2 \\
\text { r.n. }\end{array}$ \\
\hline
\end{tabular}

r.n. - różnica nieistotna - not significant difference

Tabela 3. Średni stopień porażenia bulw porażonych przez Rhizoctonia solani w zależności od sposobów stosowania UGmax i odmian Table 3. Mean degree of tuber infection by Rhizoctonia solani depending on the methods of use UGmax and cultivars

\begin{tabular}{|c|c|c|c|}
\hline \multirow{3}{*}{$\begin{array}{l}\text { Sposoby stosowania UGmax } \\
\text { Methods of use UGmax }\end{array}$} & \multicolumn{3}{|c|}{$\begin{array}{l}\text { Średni stopień porażenia bulw porażonych przez Rhizoctonia solani } \\
\text { (skala 1-9) } \\
\text { Mean degree of tuber infection by Rhizoctonia solani (scale 1-9) }\end{array}$} \\
\hline & \multicolumn{2}{|c|}{$\begin{array}{c}\text { odmiany ziemniaka } \\
\text { potato cultivars }\end{array}$} & \multirow{2}{*}{$\begin{array}{c}\text { średnio } \\
\text { mean }\end{array}$} \\
\hline & Satina & Tajfun & \\
\hline $\begin{array}{l}\text { Obiekt kontrolny - pielęgnacja mechaniczna } \\
\text { Control object - mechanical weeding }\end{array}$ & 5,85 & 6,29 & 6,07 \\
\hline UGmax $1,0+0 \mathrm{dm}^{3} / \mathrm{ha}$ & 6,17 & 6,93 & 6,55 \\
\hline UGmax $0,5+0,25+0,25 \mathrm{dm}^{3} / \mathrm{ha}$ & 6,22 & 7,06 & 6,64 \\
\hline UGmax $1,0+0,25+0,25 \mathrm{dm}^{3} / \mathrm{ha}$ & 6,30 & 7,24 & 6,77 \\
\hline UGmax $0+0,5+0,5 \mathrm{dm}^{3} / \mathrm{ha}$ & 6,11 & 6,58 & 6,34 \\
\hline Średnio - Mean & 6,13 & 6,82 & 6,48 \\
\hline $\begin{array}{l}\text { NIR }(0,05) \text { - LSD }(0.05) \text { dla - for: } \\
\text { Odmiany - Cultivars } \\
\text { Sposoby stosowania UGmax - Methods of use } \\
\text { Odmiany } \times \text { sposoby stosowania UGmax - Cult }\end{array}$ & use UGmax & & $\begin{array}{l}0,27 \\
0,53 \\
\text { r.n. }\end{array}$ \\
\hline
\end{tabular}

r.n. - różnica nieistotna - not significant difference

Tabela 4. Średni stopień porażenia próby przez Rhizoctonia solani w zależności od sposobów stosowania UGmax i lat badań Table 4. Mean degree of tuber infection by Rhizoctonia solani depending on the methods of use UGmax and years

\begin{tabular}{|c|c|c|c|c|}
\hline \multirow{3}{*}{$\begin{array}{l}\text { Sposoby stosowania UGmax } \\
\text { Methods of use UGmax }\end{array}$} & \multicolumn{4}{|c|}{$\begin{array}{l}\text { Średni stopień porażenia bulw (skala 1-9) } \\
\text { Mean degree of tuber infection (scale 1-9) }\end{array}$} \\
\hline & \multicolumn{3}{|c|}{ lata - years } & \multirow{2}{*}{$\begin{array}{c}\text { średnio } \\
\text { mean }\end{array}$} \\
\hline & 2008 & 2009 & 2010 & \\
\hline 1 & 2 & 3 & 4 & 5 \\
\hline $\begin{array}{l}\text { Obiekt kontrolny - pielęgnacja mechaniczna } \\
\text { Control object - mechanical weeding }\end{array}$ & 8,47 & 8,08 & 8,92 & 8,49 \\
\hline UGmax $1,0+0 \mathrm{dm}^{3} / \mathrm{ha}$ & 8,75 & 8,58 & 8,99 & 8,77 \\
\hline UGmax $0,5+0,25+0,25 \mathrm{dm}^{3} / \mathrm{ha}$ & 8,82 & 8,63 & 9,00 & 8,82 \\
\hline UGmax $1,0+0,25+0,25 \mathrm{dm}^{3} / \mathrm{ha}$ & 8,84 & 8,74 & 8,99 & 8,86 \\
\hline
\end{tabular}




\begin{tabular}{|c|c|c|c|c|}
\hline 1 & 2 & 3 & 4 & 5 \\
\hline UGmax $0+0,5+0,5 \mathrm{dm}^{3} /$ ha & 8,65 & 8,42 & 9,00 & 8,69 \\
\hline Średnio - Mean & 8,71 & 8,49 & 8,98 & 8,73 \\
\hline $\begin{array}{l}\text { NIR }(0,05)-\text { LSD }(0.05) \text { dla - for: } \\
\text { Lata - Years } \\
\text { Sposoby stosowania UGmax - Methods of use UGmax } \\
\text { Lata } \times \text { sposoby stosowania UGmax - Years } \times \text { methods }\end{array}$ & & & & $\begin{array}{c}0,07 \\
0,14 \\
\text { r.n. }\end{array}$ \\
\hline
\end{tabular}

r.n. - różnica nieistotna - not significant difference

Tabela 5. Porażenie bulw ziemniaka przez Rhizoctonia solani w latach badań (w \% i skali 1-9)

Table 5. Infection of potato tubers by Rhizoctonia solani during the years of research (in \% and scale 1-9)

\begin{tabular}{|c|c|c|c|c|c|}
\hline \multirow{2}{*}{$\begin{array}{l}\text { Wyszczególnienie } \\
\text { Specification }\end{array}$} & \multicolumn{3}{|c|}{ Lata - Years } & \multirow{2}{*}{$\begin{array}{l}\text { Średnio } \\
\text { Mean }\end{array}$} & \multirow{2}{*}{$\begin{array}{l}\text { NIR }(0,05) \\
\operatorname{LSD}(0.05)\end{array}$} \\
\hline & 2008 & 2009 & 2010 & & \\
\hline $\begin{array}{l}\text { Procent bulw porażonych } \\
\text { Percentage of infected tubers }\end{array}$ & 9,7 & 12,6 & 0,9 & 7,7 & 1,5 \\
\hline $\begin{array}{l}\text { Średni stopień porażenia próby (skala } 1-9 \text { ) } \\
\text { Mean degree of a sample infection (scale } 1-9 \text { ) }\end{array}$ & 8,71 & 8,49 & 8,98 & 8,73 & 0,07 \\
\hline $\begin{array}{l}\text { Średni stopień porażenia bulw } \\
\text { przez Rhizoctonia solani (skala 1-9) } \\
\text { Mean degree of tuber infection } \\
\text { by Rhizoctonia solani (scale } 1-9 \text { ) }\end{array}$ & 6,23 & 5,20 & 8,00 & 6,48 & 0,42 \\
\hline
\end{tabular}

pozostałych lat badań i wynosiła średnio $15,6^{\circ} \mathrm{C}$. Natomiast największy procent bulw chorych odnotowano w 2009 roku, kiedy miesiące czerwiec i sierpień były chłodne. Ponadto sezon wegetacyjny 2009 roku odznaczał się nierównomiernie rozłożonymi opadami w okresie tworzenia i dojrzewania bulw. Podobny wpływ warunków meteorologicznych na rozwój Rhizoctonia solani wykazały Lutomirska i Jankowska (2013), które stwierdziły, że rozwojowi sklerocjów na bulwach ziemniaka sprzyjały okresy długotrwałego uwilgotnienia gleby. Agrios (2005) stwierdził, że niższa temperatura powietrza nie sprzyja rozwojowi roślin, ich rozwój może być zahamowany, natomiast w tym czasie wzrasta nasilenie objawów występowania choroby. Podobny wpływ warunków pogodowych odnotował również Wróbel (2006) oraz Zarzecka i wsp. (2011).

\section{Wnioski / Conclusions}

1. Użyźniacz Glebowy UGmax stosowany w różnych dawkach i terminach ograniczał procentowy udział bulw z objawami rizoktoniozy, stopień porażenia bulw $\mathrm{i}$ stopień bulw porażonych $\mathrm{w}$ porównaniu do bulw zebranych z obiektu kontrolnego, na którym nie aplikowano preparatu UGmax.

2. Mniejszy udział bulw z objawami rizoktoniozy oraz mniejszy stopień porażenia bulw odnotowano u odmiany Satina w porównaniu z odmianą Tajfun.

3. O występowaniu rizoktoniozy i stopniu porażenia bulw decydowały warunki atmosferyczne panujące w okresie wegetacji roślin ziemniaka. Niska temperatura powietrza i duża wilgotność sprzyjały rozwojowi rizoktoniozy.

\section{Literatura / References}

Agrios G.N. 2005. Plant Pathology. Academic Press INC, London, 338 pp.

Atkinson D., Thornton M.K., Miller J.S. 2010. Development of Rhizoctonia solani on stems, stolons and tubers of potatoes. I. Effect of inoculum source. American Journal of Potato Research 87 (4): 374-381.

Bernat E. 2007. Wpływ stosowania użyźniacza glebowego na plonowanie i zdrowotność ziemniaków. Materiały Konferencji Naukowo-Szkoleniowej „Nasiennictwo i ochrona ziemniaka”. Kołobrzeg, 19-20 kwietnia 2007: 43-46.

Bernat E., Osowski J. 2006. Wpływ różnych terminów zaprawiania na tempo wschodów i zdrowotność ziemniaka. [The influence of different seed dressing date on the emergencje rate and healthiness of potato]. Progress in Plant Protection/Postępy w Ochronie Roślin 46 (1): 401-407.

Boligłowa E., Gleń K. 2008. Assessment of effective microorganism activity (EM) in winter wheat production against fungal diseases. Ecological Chemistry and Engineering 15 (1-2): 23-27.

Cwalina-Ambroziak B., Wróbel E. 2005. Wpływ nawożenia azotem na występowanie ważniejszych chorób na bulwach ziemniaka. Biuletyn Instytutu Hodowli i Aklimatyzacji Roślin 237/238: 169-176.

Jeske M., Pańka D., Wichrowska D. 2015. Wpływ ochrony chemicznej, nawożenia organicznego oraz użyźniacza glebowego UGmax na zdrowotność bulw ziemniaka. [Effect of chemical protection, organic fertilization and UGmax soil conditioner on health status of potato tubers]. Progress in Plant Protection/Postępy w Ochronie Roślin 55 (1): 92-97.

Lehtonen M., Ahvenniemi P., Wilson P., German-Kinari M., Valkonen J. 2008a. Biological diversity of Rhizoctonia solani (AG-3) in a northern potato-cultivation environment in Finland. Plant Pathology 57: 141-151. 
Lehtonen M., Somervuo P., Valkonen J. 2008b. Infection with Rhizoctonia solani induces defence genes and systemic resistance in potato sprouts grown without light: implications of dynamic plant-pathogen interplay underground. Phytopathology 98: 1190-1198.

Lutomirska B., Jankowska J. 2013. Ospowatość bulw zaawansowanych materiałów hodowlanych ziemniaka. [Black scurf in tubers of the potato advanced breeding material]. Progress in Plant Protection/Postępy w Ochronie Roślin 53 (4): 789-795.

Roztropowicz S. (red.). 1999. Metodyka obserwacji, pomiarów i pobierania prób w agrotechnicznych doświadczeniach z ziemniakiem. Praca zbiorowa. Instytut Hodowli i Aklimatyzacji Roślin Radzików, Oddział Jadwisin, 50 ss.

Sadowski Cz. 2006. Stan zdrowotności polskiego ziemniaka i jej zagrożenia. Zeszyty Problemowe Postępów Nauk Rolniczych 511 (1): 37-51.

Trawczyński C. 2007. Wykorzystanie użyźniacza glebowego w uprawie ziemniaka. Ziemniak Polski 3: 26-29.

Wales S., Platt H.W., Cattlin N. 2008. Diseases, Pests and Disorders of Potatoes. A Colour Handbook. Manson Publishing Ltd., London: 75-76.

Walters D., Havis N., Paterson L., Taylor J., Walsh D. 2011. Cultivar effects on the expression of induced resistance in spring barley. Plant Disease 5: 596-600.

Wróbel S. 2006. Wpływ podkiełkowywania sadzeniaków na plon oraz porażenie bulw ospowatością i parchem zwykłym. Acta Scientiarum Polonorum Agricultura 5 (1): 93-101.

Zarzecka K., Gugała M., Milewska A. 2011. Oddziaływanie użyźniacza glebowego UGmax na plonowanie ziemniaka i zdrowotność roślin. [Effect of soil fertilizer UGmax on potato yielding and plant health]. Progress in Plant Protection/Postępy w Ochronie Roślin 51 (1): 153-157.

Zimny L., Wacławowicz R., Oliwa T. 2006. Porażenie bulw przez Rhizoctonia solani w zależności od systemów uprawy ziemniaka. [Tuber infestation by Rhizoctonia solani in relation to cultivation systems of potato]. Progress in Plant Protection/Postępy w Ochronie Roślin 46 (1): 388-394. 